\title{
Identification of Student' Critical Thinking Ability in Solving Open Ended Mathematics Problem Viewed From Cognitive Styles
}

\author{
Masriyah $^{1}$, Khofidhotur Rofiah ${ }^{2}$, Umi Hanifah $^{3}$ \\ \{masriyah@unesa.ac.id ${ }^{1}$, khofidhoturrofiah99@gmail.com² ${ }^{2}$ umihanifah@itsnupasuruan.ac.id ${ }^{3}$ \} \\ Universitas Negeri Surabaya, Surabaya ${ }^{1,2}$, Institut Teknologi dan Sains Nahdlatul Ulama Pasuruan, \\ Pasuruan $^{3}$
}

\begin{abstract}
The research purpose is to identify student' critical thinking ability in problem solving based on their cognitive styles. The research subjects are two student who have reflective or impulsive cognitive style. The data were collected by giving cognitive style, mathematics ability, and problem solving tests, and interview. The research result showed that the reflective student has seven indicators of critical thinking ability; they are the ability to comprehend and express the meaning of information, distinguish relevant and irrelevant information, analyze the data, collect and organize information, find ways of completion, draw conclusions, and evaluate the completion. Based on the level of critical thinking, she is very critical. While impulsive student has four of the seven indicators of critical thinking ability, they are the ability to comprehend and express the meaning of information, distinguish relevant and irrelevant information, collect and organize information, and draw conclusions.
\end{abstract}

Keywords: Critical Thinking Abilities, Problem Solving, Cognitive Style

\section{Introduction}

The ability to think critically is one of the goals of mathematics learning. It is stated in Permendikbud Number 21 of 2016 [1] concerning the Standard Content of Primary and Secondary Education that the competence of student that must be achieved through learning mathematics is "showing a logical attitude, critical, analytical, careful and thorough, responsible, responsive, and not easily give up in solving the problem". Ennis [2] reveals that critical thinking is reasonable and reflective thinking that is focused on deciding what to believe and do. According to Fisher [3], in critical thinking student do not directly draw conclusions or do not just take decisions but really think about them. With regard to critical thinking skills, Facione [4] suggests that there are six critical thinking skills, namely (1) interpretation, (2) analysis, (3) evaluation, (4) inference, (5) explanation, (6) self-regulation.

In this study, researchers state that critical thinking abilities include the ability to (1) understand and express the meaning of information, (2) distinguish relevant and irrelevant information, (3) analyze data, (4) collect and compile information, (5) find solutions, (6) draw conclusions, and (7) evaluate the solutions made.

Fisher reveals that critical thinking is regarded as academic competence as well as reading and writing that are equally important. Therefore thinking needs to be taught to student. One tool that can be used to foster student' critical thinking skills is problem solving. As revealed by 
Trilling \& Fadel [5] that critical thinking can be learned through problem solving activities. The results of Indriyani and Masriyah's research [6] also showed that the problem solving learning model the average score of student learning outcomes reached 84.15. These high learning outcomes indicate the capability of student in solving problems applying their critical thinking skills. According to Siswono [7], problem solving is an individual process or effort in responding to and overcoming obstacles or obstacles when the answer or method to determine the solution is not yet clear. Polya [8] suggests that there are four steps in solving mathematical problems, namely (1) understanding the problem, (2) making plans, (3) implementing plans, and (4) re-examining the results of the solutions obtained.

In connection with problem solving, according to Foong [9], mathematical problems can be divided into two, namely closed problems and open-ended problems. According to Suherman, et al [10] closed problems are problems that are formulated with right or wrong answers where the right answer is only one solution while open-ended problem is formulated problem that has some correct answers. In this study an open-ended problem was used. This is because according to Kaur [11], giving open problems requires student to think more intensively and provide more solutions that involve more than just remembering facts or repeating skills. So that the provision of open-ended problems might enable student to think critically.

In problem solving, student will use various strategies. According to Susan \& Collinson [12] that, "general problem solving strategies such as these are further influenced by cognitive style". What is meant is that problem solving strategies have been influenced by student' cognitive styles. This indicates that student who have different cognitive styles, then the way to solve problems are also different, so that differences are also possible will trigger differences in their critical thinking. The results of Ningsih's research [13] can also be seen that, in general there are differences in profiles of critical thinking student with different cognitive styles.

Santrock [14] suggested that one of the cognitive styles dichotomies that are most often discussed is reflective and impulsive. Santrock (in Desminta [15]) explains that impulsivity is a cognitive style where individuals act without thinking beforehand while reflective is a cognitive style in which individuals think first and then act and usually check information slowly and carefully. Based on the description above, the researchers are interested in conducting research on "Identification of Student' Critical Thinking Ability in Open-Ended Mathematical Problem Solving from Reflective and Impulsive Cognitive Styles".

\section{Method}

The approach in this study is qualitative with the type of descriptive research. The purpose of this study is to identify student' critical thinking skills in solving open-ended mathematical problems in terms of reflective and impulsive cognitive styles. The subjects of the study were two student with reflective and impulsive cognitive styles with criteria having equivalent mathematical abilities, have same sex, had good communication, and the student were willing to be used as research subjects. Research data was collected using tests, interviews and time triangulation. The instruments used in this study were MFFT, Mathematical Ability Tests, Open-ended Mathematical Problem Solving Tests, and interview guidelines. MFFT is used to classify student into reflective and impulsive student groups. Mathematics Ability Test is used to determine equivalent mathematical abilities. Open-ended Mathematical Problem Solving Tests are used to identify student' critical thinking skills. Interviews are used to explore more about information that is not included in student' written answers. 
MFFT test results that have been done by student are analyzed by calculating the time needed by student in doing the test $(\mathrm{t})$ and calculating the number of wrong answers ( $\mathrm{f}$ ). The results of the mathematics ability test were analyzed based on the scoring guidelines made by the researchers. The results of open-ended mathematical problem solving tests and interviews were analyzed using indicators of critical thinking skills as follows.

Table 1. Indicators of student' critical thinking ability in solving mathematical problems openended.

\begin{tabular}{|c|c|c|}
\hline $\begin{array}{l}\text { Steps of Polya's } \\
\text { Problem Solving } \\
\end{array}$ & $\begin{array}{c}\text { Indicator of Critical } \\
\text { Thinking Ability } \\
\end{array}$ & Sub Indicator \\
\hline $\begin{array}{l}\text { Understand } \\
\text { the problem. }\end{array}$ & $\begin{array}{l}\text { A1: The ability to } \\
\text { understand and express } \\
\text { the meaning of } \\
\text { information } \\
\text { A2: The ability to } \\
\text { distinguish relevant and } \\
\text { irrelevant information } \\
\text { A3: Ability to analyze } \\
\text { data }\end{array}$ & $\begin{array}{l}\text { - Able to explain in detail the flow of problems } \\
\text { in the problem } \\
\text { - Able to mention what is known and asked } \\
\text { - Able to mention relevant information } \\
\text { - Able to mention irrelevant information } \\
\text { - Explain the relationship between information } \\
\text { used to solve problems }\end{array}$ \\
\hline $\begin{array}{l}\text { Devise a plan } \\
\text { (translate) }\end{array}$ & $\begin{array}{l}\text { A4: Ability to collect and } \\
\text { compile information } \\
\text { A5: The ability to find } \\
\text { solutions. }\end{array}$ & $\begin{array}{l}\text { - Able to determine a theorem or concept that } \\
\text { is useful for completion } \\
\text { - Able to develop steps to be used in the } \\
\text { settlement } \\
\text { - Able to develop other steps that can also be } \\
\text { used in settlement }\end{array}$ \\
\hline $\begin{array}{l}\text { Carry out the } \\
\text { plan (solve). } \\
\text { Look back (check } \\
\text { and interpret). }\end{array}$ & $\begin{array}{l}\text { A6: Ability to draw } \\
\text { conclusions } \\
\text { A7: Ability to evaluate the } \\
\text { solution made }\end{array}$ & $\begin{array}{l}\text { - Able to make conclusions according to the } \\
\text { request for questions } \\
\text { - Able to correct errors at the settlement made }\end{array}$ \\
\hline
\end{tabular}

From the results of the problem solving test and the results of the interview, what indicators are met. hen determined the level of critical thinking of the subject using the following criteria.

Table 2. Student critical thinking levels.

\begin{tabular}{ll}
\hline $\begin{array}{l}\text { Critical } \\
\text { Thinking Level }\end{array}$ & Characteristic \\
\hline Very critical & $\begin{array}{l}\text { Student fulfill all critical thinking abilities, namely A1, } \\
\text { A2, A3, A4, A5, A6 and A7. }\end{array}$ \\
Critical & Student fulfill 6 or 5 critical thinking skills that exist. \\
Critical enough & $\begin{array}{l}\text { Student fulfill } 4 \text { or 3 critical thinking skills that exist. } \\
\text { Less critical }\end{array}$ \\
Student fulfill 2 or 1 critical thinking skills that exist. \\
Not critical & $\begin{array}{l}\text { Student do not fulfill the ability to think critically at } \\
\text { all. }\end{array}$ \\
\hline
\end{tabular}


From the results of the cognitive style classification test (MFFT) which was attended by 32 student, 1 student had a fast accurate cognitive style, 2 student had impulsive cognitive style, 20 student had reflective cognitive style, and 9 student had a slow cognitive style. innaccurate.

Based on the results of the cognitive style classification test and the mathematical ability test the subjects were obtained as follows.

Table 3. Subjects.

\begin{tabular}{ccccccc}
\hline & & & & \multicolumn{3}{c}{ MFFT } \\
\cline { 5 - 7 } No. & Subject Initial & Sex & Math Score Test & \multirow{t}{*}{$*$} & $\boldsymbol{F}$ & $\begin{array}{c}\text { Cognitif } \\
\text { Style }\end{array}$ \\
\hline 1. & AIH & Male & 82 & 11.17 & 6 & Reflective \\
2. & AIM & Male & 82 & 4.44 & 8 & Impulsive \\
\hline
\end{tabular}

Both subjects have the same mathematical abilities, the same sex, and comic. The subjects selected were given open-ended mathematical problem solving tests and interviews.

\section{Result and Discussion}

\subsection{Identification of Critical Thinking Ability of Student with Reflective Cognitive Style in Open-ended Mathematical Problem Solving}

In understanding the problem, reflective student met the indicators of critical thinking ability, namely the ability to understand and express the meaning of information, distinguish relevant and irrelevant information, and analyze data. The ability to understand and reveal the meaning of information is shown by student being able to explain the problem flow of the given problem in detail. In explaining the flow of the problem she used her own language. This is consistent with the opinion of Santrock that reflective student make it possible to read by understanding and interpreting text. The results of Ningsih's study also mention that reflective student retell information contained in problem solving problems using their own words. She is also able to mention information that is known and asked. Some information was shown from written snswer and some other information was able to be mentioned during the interview. The ability to distinguish relevant and irrelevant information is indicated by the student being able to mention all relevant information and be able to mention information that is not relevant properly. Whereas the ability to analyze data is shown by student being able to explain the relationship between information used to solve problems, namely traveling around the rectangle with slashes to determine the distance between letters.

In developing a plan, reflective student fulfilled the indicators of critical thinking skills, namely the ability to collect and compile information and find ways of solving. The ability to collect and compile information is shown by student being able to show a theorem or concept that is useful for completion, namely the formula of plane area. Student was also able to arrange steps in completion by calculating the distance of each letter first and then determining each of the colored areas with the idea of dividing and composing a plane into a new one. The ability to find ways of solving is indicated by student being able to develop other steps that can also be used in the solution with the same idea of dividing and arranging a plane into a new one but 
with a different plane in the first way. This is in line with Ardani's (2017) research that male reflective student discuss possible steps by mentioning other steps other than those chosen.

In completing a plan, the reflective student met the indicator of the ability to draw conclusions. The ability to draw conclusions is shown by student being able to make conclusions according to the request for questions. By drawing the right conclusions shows that student can solve problems and make decisions, as revealed by Santrock that reflective student can solve problems and make decisions.

In re-examining, the reflective student met the indicator of the ability to evaluate the solution made. The ability to evaluate the solution made is shown by student being able to correct the mistakes made, namely by counting back one by one the calculation. To evaluate the solution made, she compared the total area of each color with the width of the rectangle. Because student re-examine the answers and the truth or false made so that getting the right conclusions this makes student needed a long time. This is in accordance with the reflective characteristics of children, as stated by Santrock (in Desminta) that reflective student need a long time in making decisions but the error rate is low due to thinking first in making decisions and then acting and checking information slowly and carefully.

\subsection{Identification of Critical Thinking Ability of Student with Reflective Cognitive Style in Open-ended Mathematical Problem Solving}

In understanding the problem, impulsive student met the indicators of critical thinking ability, namely the ability to understand and express the meaning of information and distinguish relevant and irrelevant information, but student did not fulfill the indicator of the ability to analyze data. The ability to understand and reveal the meaning of information is indicated by student being able to mention information that is known and asked. Some information was shown from written answer and some other information was able to be mentioned during the interview. Although in explaining the problem paths of the given questions, she is not able to explain well, but she still consider to have the ability to understand and reveal the meaning of information. In explaining the flow of problems, she immediately mention what is known without thinking for a long time and not trying to explain in their own language. This is consistent with the research of Ningsih that impulsive student in retelling tends that the words used are the adoption of what is in the problem and also the opinion of Kagan [16] that impulsive students in making decisions require fast time. The ability to distinguish relevant and irrelevant information is indicated by the student being able to mention all relevant information and be able to mention information that is not relevant properly. While student did not have the ability to analyze data because student was not able to explain the relationship between information used to solve problems, namely not being able to pull the peripheral connection with slashes to determine the distance between letters.

In compiling plans, impulsive student meet the indicator of the ability to collect and compile information but student do not meet the indicator of the ability to find ways of solving. The ability to collect and compile information is shown by student being able to show a theorem or concept that is useful for completion, namely the formula for flat building area. Student are also able to arrange steps in completion by calculating the distance of each letter first and then determining each colored area with the idea of calculating the building area that appears in each colored area. While student do not have the ability to find ways of solving because student are not able to develop other steps that can also be used in settlement.

In completing a plan, impulsive student fulfilled an indicator of the ability to draw conclusions. The ability to draw conclusions is shown by she was able to make conclusions in 
accordance with the request of the question even though from the answers given there are still any parts that are wrong.

In reexamining, she did not fulfill the indicator of the ability to evaluate the settlement made. This is because student was unable to correct mistakes made. In solving the questions given student need a fast time this is because student do not make alternative solutions and do not check the answers so that there are still any mistakes that have not been fixed. This is in accordance with the characteristics of impulsive children as stated by Santrock (in Desminta) that impulsive children in making decisions require a faster time because they act without thinking, so the error rate is high.

\subsection{Identification of Critical Thinking Ability of Student with Reflective Cognitive Style in Open-ended Mathematical Problem Solving}

The ability to think critically of reflective and impulsive students in solving open-ended problems showed differences. In understanding the problem reflective and impulsive students both fulfilled indicators of ability to understand and express the meaning of information and the ability to distinguish relevant and irrelevant information. Reflective student fulfilled indicators of ability to analyze data but impulsive student did not meet the indicator of ability to analyze data.

In compiling the problem reflective and impulsive students both fulfilled the indicator of the ability to collect and compile information. Reflective student fulfilled the indicator of the ability to find ways of completion, but impulsive student did not meet the indicator of the ability to find ways of solving. In implementing, reflective and impulsive students both meet the indicator of the ability to draw conclusions. In re-examining reflective student met the indicator of the ability to evaluate the solution made while impulsive student did not meet the indicator of the ability to evaluate the solution made.

\section{Conclusion}

Overall, in solving open-ended problems student met seven indicators of critical thinking ability, namely the ability to understand and express the meaning of information, distinguish relevant and irrelevant information, analyze data, collect and compile information, find ways of solution, draw conclusions, and evaluate the solution made. So that, based on the level of critical thinking, she is categorized as very critical. Overall in solving open-ended problems student met four of the seven indicators of critical thinking ability, namely the ability to understand and express the meaning of information, distinguish relevant and irrelevant information, collect and compile information, and draw conclusions. So that, based on the level of critical thinking, she is critical enough.

\section{References}

[1] Kemendikbud.: Permendikbud Number 21 Year 2016 aboutg Content Standards for Elementeryy and Secondary Education. Jakarta: Kemendikbud. 2016. [Online]. Available: http://bsnpindonesia.org/standar-isi/. [4 January 2018]. 
[2] Ennis. R.H.: The Nature of Critical Thinking: An Outline of Critical Thinking Dispositions and Abilities. 2011. [Online]. Available: http://faculty.education. illinois.edu/rhennis/documents/TheNatureofCriticalThinking_51711_000.pdf. [March 5, 2017].

[3] Fisher, A.: Berpikir Kritis Sebuah Pengantar. Translated by Erlangga. Jakarta: Erlangga. (2011)

[4] Facione, P.A.: Critical Thinking: A Statement of Expert Consensus for Purposes of Educational Assessment and Instruction. California: Eric. 1990. [Online]. Available: https://eric.ed.gov/?id=ED315423. [December 25th, 2017]

[5] Trilling, B. and Fadel, C.: 21st Century Skills. San Francisco: Jossey-Bass. 2009. [Online]. Available: https://yasamboyuogrenme. wikispaces.com /file/ view/ 21st+ CENTURY+SKILLS.pdf. [October 18, 2017].

[6] Indriyani, R.W and Masriyah.: Penerapan Model Pembelajaran Ideal Problem Solving dalam Menyelesaian Masalah Metematika pada Materi Keliling dan Luas Persegipanjang dan Persegi bagi Siswa Kelas VII SMP. Vol. 2, Nomor 5, 2018, [Online]. Available: http://jurnalmahasiswa.unesa.ac.id/index.php/mathedunesa/article/view/16685/15155 $\quad$ 15.pdf, $\quad$ [20 November 2018].

[7] Siswono, T.Y. E.: Model Pembelajaran Matematika Berbasis Pengajuan Masalah dan Pemecahan Masalah Untuk Meningkatkan Kemampuan Berpikir Kreatif. Surabaya: Unesa University Press. (2008) [8] Polya, G. Second Edition. New Jersey: Princeton University Press. 2017 [Online]. Available: https://notendur.hi.is/ hei2/ teaching / Polya_How ToSolveIt.pdf, [17 October 2017].

[9] Foong, P. Y.: The Role of Problems to Enhance Pedagogical Practices in the Singapore Mathematics Classroom. Vol. 6, Nomor 2, pp. 15-31, 2002. [Online]. Available: https://repository. nie.edu.sg/bitstream/10497/52/1/TME-6-2-15.pdf, [14 October 2017]

[10] Suherman, E. cs.: Strategi Pembelajaran Matematika Kontemporer. Bandung: JICA. (2003)

Kaur, B. (Eds).: Mathematical Problem Solving. Singapore: World Scientific Publishing. (2009)

[11] Susan, H. and Collinson, G.: Achieving Evidence-Based Practice: A Handbook for Partitioners.Second Edition. Elsevier. (2005)

[12] Ningsih, P.R.: Profil Berpikir Kritis Siswa dalam Menyelesaikan Masalah Matematika berdasarkan Gaya Kognitif, Vol 2, Nomor, 2, 2012, [Online]. Available: http://www. journal. unipdu. ac. id/ index. $\mathrm{php} /$ gamatika/article/ view/279, [6 March 2017]

[13] Santrock, J.W.: Psikologi Pendidikan. Second Edition. Translated by Penerbit Erlangga. Jakarta: Kencana.(2010)

[14] Desminta.: Psikologi Perkembangan Peserta Didik. Bandung: PT Remaja Rosdakarya. (2009)

[15] Kagan, J.: Reflection-impulsivity: The generality and dynamics of conceptual tempo. Journal of Abnormal Psychology, 71, pp. 17-24. (1966) 